\title{
FOREIGN DIRECT INVESTMENT AND ECONOMIC GROWTH: TWO EQUALLY DESIRABLE DILEMMAS OF POLICY MAKERS IN INDIA
}

\author{
Piyali Roy Chowdhury \\ Research Scholar, Department of Management, \\ Vellore Institute of Technology Business School, \\ Vellore Institute of Technology, Chennai, Tamil Nadu, India \\ A Anuradha \\ Associate Professor, Department of Management, \\ Vellore Institute of Technology Business School, \\ Vellore Institute of Technology, Chennai, Tamil Nadu, India
}

\begin{abstract}
The study aims to analyze the importance of economic growth that has more relevance than Foreign Direct Investment (FDI) inflow for a stable development in India. The article takes the period of 1978 to 2019 to analyze the same. It applies Auto Regressive Distributed Lag Modelling Approach to find out the impact of economic growth. It is proved that there is a cointegration between FDI and economic growth in long run. In short run, both economic growth and FDI granger cause each other. Also, there exists a negative effect of FDI on economic growth in short run. Hence, the study recommends a threefold development process in India. The policy makers are suggested aligning the economic policies in a way to focus at the first stage only on economic growth which will bring FDI in India. At the second stage, they need to find relevant macroeconomic variables that will be positively influenced by FDI so that, at the third stage, these variables will ultimately contribute to growth of Indian economy.
\end{abstract}

Key words: FDI, Economic growth, ARDL, Granger Causality, India.

Cite this Article: Piyali Roy Chowdhury and A Anuradha, Foreign Direct Investment and Economic Growth: Two Equally Desirable Dilemmas of Policy Makers in India, International Journal of Management, 11(9), 2020, pp. 903-915.

http://iaeme.com/Home/issue/IJM?Volume $=11 \&$ Issue $=9$ 
Foreign Direct Investment and Economic Growth: Two Equally Desirable Dilemmas of Policy Makers in India

\section{INTRODUCTION}

Economic growth has always been considered as a prominent indicator for the development of an economy. As specified in Fayissa, et al (2008), industrial contribution is one of the major influencers of Gross Domestic Product (GDP) and economic growth in Africa. Country specific studies show different reasons and macroeconomic variables for the support of the growth of any economy. Based on the nature of an economy, that is, developed or developing, the policy regimes, political and social factors also influence the growth rate of economy.

The importance of economic growth has always been related with either domestic or foreign investment. As correctly identified by Abu and Karim (2016), domestic investment helps a country to spur with better higher growth of GDP. Along with domestic, foreign funds also contribute to the growth of a nation by enhancing different macroeconomic variables. Adedoyin, et al. (2020) identified information and communication technology is highly related with foreign investment, specifically, Foreign Direct Investment (FDI) to contribute to the growth rate of an economy. Thus, we find several studies that explains FDI led growth theory as well as growth led FDI theory. The applicability of those two theories differs according to the structure and stage of development of a country.

Although there are many analyses articulated on FDI led growth hypothesis, there are handful of studies that have been constructed on growth led FDI hypothesis. In this respect, the current study aims to find out the importance of economic growth on inflow of FDI in India. It takes Auto Regressive Distributed Lag (ARDL) modelling approach to prove and analyze long run cointegration among the two variables. After determining the cointegration, it aims to analyze the short run scenario by applying error correction model. The percentage chance from short run instability to long run stability is judged here. After that, the model determines the possibility of granger causality between the variables by applying Granger causality test.

The structure of the article is demonstrated as follows: Section two explains review of the literature. Section three elaborates on the theoretical framework. Section four explores the conceptual framework extracted from the theories. Section five describes the methods of data collection and analysis of the data. Section six illustrates findings and analysis. Section seven enters the discussion. Section eight analyses conclusion and section nine provides possible recommendations and limitations of the study

\section{REVIEW OF LITERATURE}

Various studies have been undertaken on judging the relationship between Foreign Direct Investment (FDI) and economic growth. The several studies analyses impact of FDI on economic growth and its interrelations in short run. We segregate the impact analysis of FDI on economic growth and economic growth on FDI into two different sections in this current study. Based on these literatures, the gap of the studies is identified.

\subsection{Effect of Foreign Direct Investment (FDI) on Economic Growth}

Sunde (2017) explained the impact of foreign direct investment and export on economic growth in South Africa. Also, through cointegration, the association between the above variables were justified. For short run dynamics, the granger causality explored a unidirectional causality from foreign direct investment to economic growth. Ali and Mna (2019) analyzed the effect of FDI on domestic investment and economic growth in three economies- Algeria, Tunisia and Morocco. Adedoyin, et al. (2020) analyzed the impact of energy, air transport and FDI on economic growth. The result claimed that there would be necessary linkages between FDI and economic growth in USA. Osei and Kim (2020) 
investigated the impact of financial development on growth of the economy. The study proved the influence of FDI would become insignificant if private sector investment takes more than ninety percent share of Gross Domestic Product (GDP) in any economy. Asongu and Odhiambo (2020) proved that mobile and internet penetration had helped economies to promote FDI inflows and that gradually followed growth in economies. Akisik, et al (2020) enhanced the importance of FDI through International Financial Reporting Standards (IFRS) and claimed in the article that openness of the economy, corruption and schooling had positive impact on IFRS. The IFRS, in return, would bring economic growth to a country taken for the specific study. Alvarado, et al. (2017) analyzed the impact of FDI on economic growth considering the three-specific type of economies- such as, high income, upper middle income, and lower middle-income economies in Latin America. High income economies had positive, upper middle-income oriented economies had unstructured and statistically insignificant and lower middle-income economies had negative influence of FDI on economies growth. Thus, the outcome of the economies was different with respect to size of the market in respective countries. Qureshi, et al. (2020) analyzed corruption control always strongly had impacted inflows of FDI and growth of the economy for developed economies. The opposite would happen to the developing economies in this respect. Lee, et al. (2020), opposing to Hong, et al (2019), examined the influence of FDI on labor employment taking proxy variables as motivation and activity, following the work of De Long (1992). Wang and Jiayu (2019) explored the impact of FDI on the structure, scale and energy creation in an economy. It proved that FDI helped to create positive impact on energy creation and thus indirectly helped initiating the growth of the economy. Fan and Hao (2020) in China explored a long run cointegration among renewable energy, FDI and economic growth. The short run causality showed both moderate growth and FDI will enhance energy consumption in Chinese economy. Sokhanvar (2019) explained the direct and indirect impact of FDI on economic growth in European economies. The analysis revealed that the receipts from tourism and FDI incorporate the growth of the economy. Latif, et al. (2018) explained FDI as the main contributor to long run economic growth in BRICS economies. Makiela and Ouattara (2018) investigated the impact of FDI on economic growth and proved that FDI created accrual of inputs and defended about productivity. Hanif, et al. (2019) proved FDI to be a part of cause of decrease in the growth rate of the economy. The study investigated that FDI would bring forth the degradation of environment and thus long run economic growth would be hampered in the developing economies. Apart from FDI, domestic investment would also be helpful in determining the level of economic growth in Thailand, as specified by Raza (2020).

\subsection{Effect of Economic Growth on Foreign Direct Investment (FDI)}

Apart from well-defined impact analysis of FDI to economic growth, the reverse study has also been conducted in few literatures. One of the most significant among them is Berthélemy and Demurger (2000). It specified Keynes- Ramsey condition that again led to confirm the positive impact of economic growth in local countries on FDI. Cadman (2015) analyzed the influence of economic growth on FDI in Kenya. The study proved the increment in growth rate would enhance the level of FDI in this economy. Following Chakrabarti (2001), it showed that size of the local economy, defined as a market size and a proxy for per capita Gross Domestic Product (GDP), that helped strengthening the flow of FDI into destination countries. As laid by Lim (1983), the foreign investors would be highly interested if an economy had already acquired the desirable growth rate than the other host countries in world. Lunn (1980), Culem (1988), Tsai (1994) and Billington (1999) determined size of the market and economic growth as factors determining direct investment pattern in United States of America. Schneider and Frey (1985) proved higher values of per capita real Gross National Product (GNP) will reduce the level of deficit of Balance of Payment(BOP) and this reduced 
gap of BOP will strengthen the flow of FDI in host countries characterized as developing economies. Canh et al. (2020) investigated and proved a negative influence of local uncertainty in economic policy on FDI at world level. Also, the analysis found out that combining local uncertainty and world level economic uncertainty, the result showed a positive effect on FDI. Hsieh, et al. (2019) analyzed the causality between economic policy uncertainty index and FDI outflow in USA. The analysis confirmed to create a strong economic policy to forecast a desirable amount of FDI outflow in USA. Hong, et al (2019) examined the influence of labor employment, proxied by the factor motivation, was proved to be one of the prominent factors affecting FDI outflow. Kumari and Sharma (2018) analyzed the contribution of GDP towards inflow of FDI in India.

Discussing the above literatures, the specific analysis over India is found to be present in negligible studies. Although Kumari and Sharma (2018) made their contribution analyzing the long run cointegration among electricity consumption, FDI and growth of the economy in India, the study fails to analyze the direction of causality in long run and short run. The analysis laid no significant outcome on the coefficient variables taken into the study. The two cointegrating equations that are statistically significant do not clearly examine the impact of the explanatory variables in a Vector Autoregressive (VAR) framework. Thus, in this current study, the article tries to find out the direction of causality in long run through Auto Regressive Distributed Lag Modelling (ARDL) Approach. This method enables to find out impact of the explanatory variable in long run as well as in short run through Error Correction Model. Finally, through Granger causality, it tries to find out the simultaneous past influences of the underlying variables in the model. Also, the present article covers broader period than Kumari and Sharma (2018) as it has considered the data ranging between 1978 and 2019.

\section{THEORETICAL FRAMEWORK}

There remain several theories concentrating on FDI led growth hypothesis for any economy. According to Dunning (1988), there can be possibilities of inflow of FDI if there exist three advantages. First, the ownership advantage that allows a foreign firm to work independently. Second, the advantage of location that enhances the stability of the foreign firm in host country. And third is the internalization policy which entails the intra firm activities rather than arm's length transaction in host country economy. The second theory is proposed by Lee (2007). It is known as factor proportion hypothesis or Flying Geese Model that explains the competitive advantage concept of factor productivity. It claims that foreign investors move from high labor cost production-oriented economies to lower cost ones to reap the benefits of the return from investments of them. Both the theories explain FDI led growth theory in any economy. Brainard (1997) developed the horizontal theory of FDI where he laid importance on foreign investors to move into the host economies that has lower transaction and tariff cost than the home countries of them.

All the theories specified above are explained based on FDI led growth hypothesis. The statement developed by Berthélemy and Demurger (2000) explained the concept of growth led FDI hypothesis. In India, following Berthélemy and Demurger (2000), we propose the conceptual framework based on economic growth led FDI hypothesis.

\section{CONCEPTUAL FRAMEWORK}

Based on the theoretical framework, the model that is built to its relevance is depicted in figure (1). The circular flow diagram first starts with economic growth that causes FDI to be brought about in India. The successful implementation of FDI policies will in turn induce the economic growth in next stage. This study stresses on the economic growth induced 
development in India through proper channelization and implementation of FDI inflow at correct time.

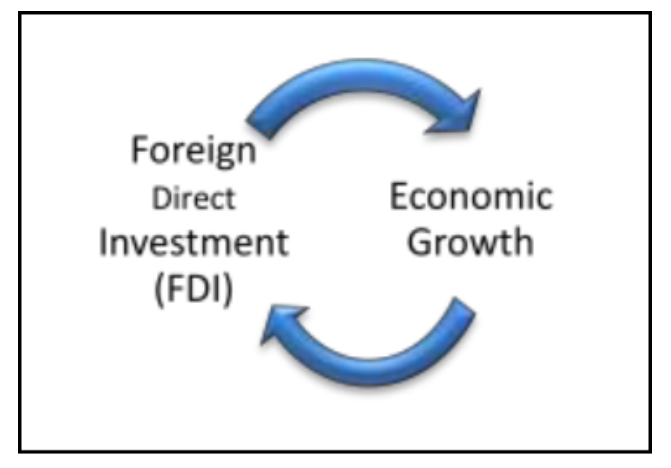

Figure 1 The Conceptual Framework

Considering the above conceptual framework, the following equations have been established.

$$
\begin{aligned}
& \Delta \ln Y_{t} \\
& =a_{1}+\sum_{i=1}^{n} \beta_{1 i} \Delta \ln Y_{(t-i)}+\sum_{j=0}^{n} \mathrm{\gamma}_{1 j} \Delta \ln X_{(t-j)} \\
& +y_{1} \ln \left[Y_{(t-1)}+y_{2} \ln \left[X_{(t-1)}\right.\right. \\
& +e_{t}
\end{aligned}
$$

$$
\begin{aligned}
& \ln Y_{t} \\
& =\Omega_{1}+\sum_{i=1}^{n} \beta_{2 i} \ln Y_{(t-i)}+\sum_{j=0}^{n} \gamma_{2 j} \ln X_{(t-j)} \\
& +\mu_{t}
\end{aligned}
$$

$$
\begin{aligned}
& \Delta \ln Y_{t} \\
& =\Pi_{1}+\sum_{i=1}^{n} \beta_{3 i} \Delta \ln Y_{(t-i)}+\sum_{j=0}^{n} \gamma_{3 j} \Delta \ln X_{(t-j)} \\
& +{ }_{\eta_{1}} E C T_{t-1} \\
& +\Psi_{t}
\end{aligned}
$$

Equation (1) explains the ARDL model specification. Equation (2) analyses long run coefficient of the underlying variables and equation (3) specifies short run model with error correction term into it.

The above equations have the following explanations:

Where,

$\mathrm{Y}_{\mathrm{t}}=$ Foreign Direct Investment (FDI),

$\mathrm{X}_{\mathrm{t}}=$ Economic growth

$\beta=$ coefficient of lagged values of FDI 
Foreign Direct Investment and Economic Growth: Two Equally Desirable Dilemmas of Policy Makers in India

$\gamma=$ coefficient of lagged values of economic growth

$\gamma=$ coefficient of one period lag of the underlying variables

$\eta_{1}=$ coefficient of error correction term

$\Omega_{1}, \alpha_{1}, \Pi_{1}=$ constants in three equations

$\mu_{\mathrm{t}} \mathrm{e}_{\mathrm{t}}, \Psi_{\mathrm{t}}=$ Error terms for three equations

\section{OBJECTIVES OF THE STUDY}

According to the conceptual framework, the objectives of the study are specified as follows:

- To find out association between economic growth and FDI in India.

- To find out the long run and short run impact of economic growth on FDI in India and vice versa.

- To find out granger causality between FDI and economic growth in India.

\section{METHODOLOGY}

\subsection{Data Collection}

To analyze the association between economic growth and FDI, the data have been collected from publicly available resources from World Bank database. The economic growth is defined as annual rate of growth measured at market prices and at local currency. FDI is classified as net inflows of foreign funds into host economy at its local currency unit. The range of data collection is 1978-2019. As they are of different units of measurements, they are transferred into logarithm and then the analysis is made.

\subsection{Data Analysis Method}

To find the association, we have two different methods. One is Johannsen cointegration and another is Auto Regressive Distributed Lag (ARDL) Modelling Approach. While Johansen as specified by Kumari and Sharma (2018) enables to find out existence of cointegration, it fails to be actively applied while data are integrated to different orders. The prerequisite of Johansen is to be applied only when data are integrated to order one. All the data after transforming may not be able to be at the same order, one. Hence as the data get stationary at maximum at their level 2, we require a different method that can be applied in this scenario. The prerequisite of ARDL is data can be stationary at different orders, may be at their level, or at first difference or at level 2, that is, at their level of second difference. To check the stationarity, we apply Augmented Dicky Fuller (ADF) test and Phillips Perron (PP) test. The application of ARDL also mentions proper direction of causality while running it, it becomes prominent to find out the necessary explanatory variables in the model. As our objective is to find out the long run cointegration between FDI and economic growth, it is appropriate to use ARDL as it specifies the value of cointegration and direction of causality as well with their respective coefficients in long run. For sort run. The model articulates Error Correction Term (ECT) with short run coefficients of the explanatory variables along with percentage of chance of movement from short run adjustments to long run stable equilibrium. Finally, the granger causality test signifies the importance and relevance of the past explanatory variables to influence the dependent variables. This method considers a Vector Autoregressive (VAR) method to consider all the variables as both explanatory and explained variables. 


\section{HYPOTHESES}

The hypothesis developed according to the objectives of the study is:

$\mathrm{H}_{01}$ : There is no long run cointegration among FDI and economic growth in India

$\mathrm{H}_{02}$ : There is no long run significant impact of economic growth on FDI in India

$\mathrm{H}_{03}$ : There is no short run significant impact of economic growth on FDI in India

$\mathrm{H}_{04}$ : There is no long run significant impact of FDI on economic growth in India

$\mathrm{H}_{05}$ : There is no short run significant impact of FDI on economic growth in India

$\mathrm{H}_{06}$ : Economic growth does not granger cause FDI in short run in India

$\mathrm{H}_{07}$ : FDI does not granger cause economic growth in short run in India

\section{RESULTS AND DISCUSSIONS}

\subsection{Augmented Dicky Fuller and Phillips Perron Test}

The drawback of the time series data is it may have pattern in its process. The trend in data causes difficulty in measuring forecast for future scenarios. It is also called unit root problem in time series. To remove the problem, the data needs to be free of trend. The detrending of the dataset can be found at level, at first difference or at second difference. Thus, according to level, first and second difference, the data are renamed as I (0), I (1) and I (2). The wellknown test statistics used in this step are Augmented Dicky Fuller (ADF) and Phillips Perron (PP). The current model produces the result of ADF and PP in table (1) and table (2).

Table 1 Result of Augmented Dicky Fuller (ADF):

\begin{tabular}{|c|c|c|c|c|}
\hline \multirow{2}{*}{$\begin{array}{c}\text { Augmented Dickey-Fuller } \\
\text { test statistic }\end{array}$} & \multicolumn{2}{|c|}{ Level } & \multicolumn{2}{|c|}{ 1st Difference } \\
\hline & t-Statistic & Probability & t-Statistic & Probability \\
\hline Economic Growth & $(6.09303) *$ & 0.0000 & \multicolumn{2}{|c|}{ NA } \\
\hline FDI & $(1.268339)$ & 0.6351 & $(6.77099) *$ & 0.0000 \\
\hline
\end{tabular}

* signifies result is significant at 5 percent level

Table 2 Result of Phillips Perron (PP):

\begin{tabular}{|l|c|c|c|c|}
\hline \multirow{2}{*}{ Phillips Perron test statistic } & \multicolumn{2}{|c|}{ Level } & \multicolumn{2}{c|}{ 1st Difference } \\
\cline { 2 - 5 } & $\begin{array}{c}\text { Adjusted t- } \\
\text { Statistic }\end{array}$ & Probability & $\begin{array}{c}\text { Adjusted t- } \\
\text { Statistic }\end{array}$ & Probability \\
\hline Economic Growth & $(6.134125) *$ & 0.0000 & \multicolumn{2}{|c|}{ NA } \\
\hline FDI & $(1.216826)$ & 0.6581 & $(8.73136) *$ & 0.0000 \\
\hline
\end{tabular}

* signifies result is significant at 5 percent level

Table (1) and (2) prove economic growth is integrated of I (0). It is stationary at its level. But FDI is stationary at its 1st difference. The different orders of the data confirm the justification of ARDL model in the next step.

\subsection{Auto Regressive Distributed Lag Modelling Approach}

The Auto Regressive Distributed Lag (ARDL) Modelling is applied when data are found to be cointegrated. The basic rule of ARDL is that it can be applied irrespective of the order of the integration of dataset. This application is an improvement of the Johansen Cointegration Test where the data are required to be integrated of the same order, order one. Many a times, the underlying variables may not be integrated of the same order. Hence, ARDL solves the problem of degree of data integration. Also, another benefit of applying ARDL is that in this process, the classification of the independent and the dependent variables can clearly be 
specified. Though Vector Autoregressive (VAR) method, it takes all the underlying variables as independent as well as dependent. Thus, it solves the endogeneity problem in the data with clear specification of type of dependency of the data and direction of causality in both long and short run. By applying Johansen cointegration, the direction of causality cannot be found. In this arena, ARDL is again an improvement over Johansen cointegration model. It also specifies the long run cointegration values which are again statistically proven by Pesaran, et al (2001). Two sets of values are specified-one for upper boundary, I (1) and one for lower boundary I (0). If the calculated cointegration value is more than the tabulated values of the upper boundary, the result carries a significant cointegration among variables. If the calculated value is less than the tabulated lower boundary, it is said that the cointegration is not present. If the calculated value falls in between upper and lower boundary, the result is ambiguous and the presence of the cointegration cannot be confirmed. The result of the cointegration is presented in table (3).

Table 3 Result of Cointegration:

\begin{tabular}{|c|c|c|c|c|c|}
\hline Test Statistic & Value & \multicolumn{2}{|c|}{ Significance (10\%) } & \multicolumn{2}{|c|}{ Significance (5\%) } \\
\hline \multirow{2}{*}{ F Statistic } & \multirow{2}{*}{$7.31^{*}$} & $\mathrm{I}(0)$ & $\mathrm{I}(1)$ & $\mathrm{I}(0)$ & $\mathrm{I}(1)$ \\
\cline { 3 - 6 } & & 3.02 & 3.51 & 3.62 & 4.16 \\
\hline
\end{tabular}

* signifies result is significant at 5 percent level

Table (3) analyses the result of cointegration. It shows that the cointegrating value is more than the upper bound level I (1), for both 5 and 10 percent level of significance. It leads to confirm the presence of cointegration among FDI and economic growth for long run. This confirms the rejection of $\mathrm{H}_{01}$. Also, the model proves no long run impact of both FDI and economic growth. This leads to accept $\mathrm{H}_{02}$ and $\mathrm{H}_{04}$.

\subsection{Error Correction Model}

The long run cointegration leads to short run error correction model. As ARDL specifies VAR framework, after confirming the direction of causality in long run, the data are put through short run causal framework. Here, the coefficient of the variables in short run can be found with percentage of error correction. This Error Correction Term (ECT) signifies the percentage of correcting errors in short run and chance of movement from short run disequilibrium to long run equilibrium. The short run model of ARDL is shown in table (4).

Table 4 Result of Short Run Error Correction Model:

\begin{tabular}{|l|c|c|c|}
\hline \multicolumn{1}{|c|}{ Variable } & Coefficient & t-Statistic & Prob. \\
\hline$\Delta \ln (\mathrm{FDI}(1))$ & $(0.002553)$ & $(0.018070)$ & 0.9857 \\
\hline$\Delta \ln (\mathrm{FDI}(2))$ & $(0.413204)^{*}$ & $(4.096386)$ & 0.0004 \\
\hline$\Delta \ln (\mathrm{FDI}(3))$ & $(0.058499)$ & $(0.556740)$ & 0.5827 \\
\hline$\Delta \ln (\mathrm{FDI}(4))$ & $(0.394839) *$ & $(3.967133)$ & 0.0005 \\
\hline$\Delta \ln (\mathrm{FDI}(5))$ & 0.014316 & 0.130678 & 0.8971 \\
\hline$\Delta \ln (\mathrm{FDI}(6))$ & $(0.335034) *$ & $(3.330896)$ & 0.0027 \\
\hline$\Delta \ln (\mathrm{Growth})$ & 0.126057 & 1.330094 & 0.1955 \\
\hline $\begin{array}{l}\text { Error Correction } \\
\text { Term }\end{array}$ & $(0.071940) *$ & $(4.867539)$ & 0.0001 \\
\hline
\end{tabular}

* signifies result is significant at 5 percent level

Table (4) shows the impact of FDI and growth for its lagged values in short run. It signifies that FDI affects short run economic growth negatively. This confirms rejection of $\mathrm{H}_{05}$. The impact of lagged values of growth is nonsignificant. It implies acceptance of $\mathrm{H}_{03}$. 
The error correction term is negative and significant. It explains the chances of the model being corrected from its disequilibrium in short run and reaching long run stability. It has seven percent chance of correction from instability causing from external shock. The R square term signifies 60 percent variance of FDI can be explained by economic growth in the current model. The adjusted $\mathrm{R}$ square is 50 percent that entails the model to be satisfactory. The Durbin Watson value here is 1.73 (approximately 2) that explains the model is free from autocorrelation. This result is again confirmed by computing Breusch-Godfrey Serial Correlation LM Test that has $\mathrm{F}$ value as 3.15 with probability 0.06 . The proof of homoskedasticity is calculated by Breusch-Pagan-Godfrey test that has $\mathrm{F}$ value as 0.7 with probability 0.7 .

\subsection{Granger Causality Test:}

While capturing the short run coefficient of the model, the problem of endogeneity considering the past influences of the underlying variables are ignored. This can be solved by applying Granger Causality (GC) Test. In short run if the endogeneity problem can be considered, there will be clarity and appropriateness in the policy implementation. Thus, GC test is very crucial at the last of the application of ARDL. The result of GC test is specified in table (5).

Table 5 Result of Granger Causality Test:

\begin{tabular}{|l|c|c|}
\hline \multicolumn{1}{|c|}{ Null Hypothesis } & F statistic & Probability \\
\hline $\begin{array}{l}\ln (\mathrm{FDI}) \text { does not granger cause } \\
\ln (\text { Growth) }\end{array}$ & $3.10558^{*}$ & 0.0304 \\
\hline $\begin{array}{l}\ln (\text { Growth) does not granger } \\
\text { cause } \ln \text { (FDI) }\end{array}$ & $4.12567^{*}$ & 0.0091 \\
\hline
\end{tabular}

* signifies result is significant at 5 percent level

Table (5) explains the result of granger causality. The result shows both FDI and economic growth granger cause each other in short run. This confirms the rejection of $\mathrm{H}_{06}$ and $\mathrm{H}_{07}$.

Apart from the above results, the model confirms underlying data to be following normal distribution as Jarque- Bera value is 1.08 with probability 0.58 . Finally, the stability of the model is judged through Cumulative Sum (CUSUM) and Cumulative Sum of Square (CUSUMQ). Figure (2) and figure (3) confirm that the model is stable.

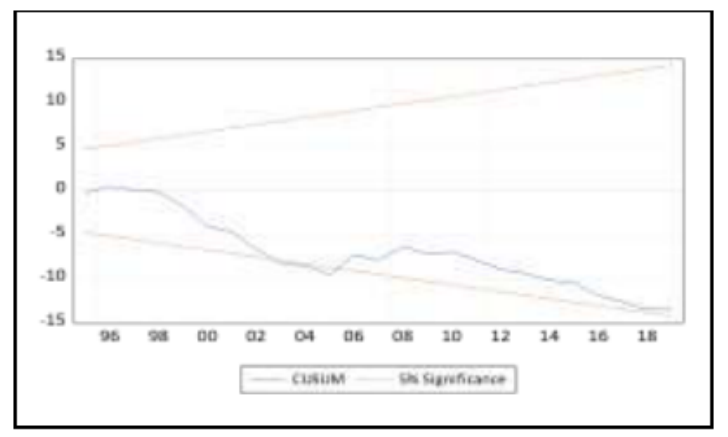

Figure 2 CUSUM test 


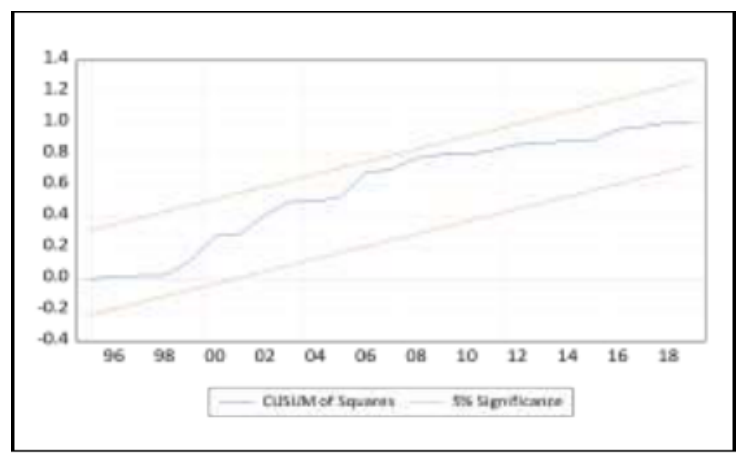

Figure 3 CUSUMQ test

\subsection{Discussion}

The current study lays its importance on the finding of the interdependence of FDI and economic growth of India. While it has already been shown in many articles that the dependency of economic growth on FDI is important, the reverse has not been found in various studies. This article has found its inference confirming that economic growth also brings FDI inflows in India. This paper gives importance on the framing of policies specially directed for augmenting short run economic growth. Growth can be induced considering overall GDP or per capita GDP. As discussed by Abu and Karim (2016), domestic investment also plays a crucial role in welcoming FDI in African economies. The role of the domestic investment in India as a host economy also needs to be figured out thoroughly in this aspect. Though domestic investment is helpful in encouraging national income of an economy, Jenkins (2006) proved the importance of FDI in creating employment in any economy. Following this model, we can also check for existence of FDI led growth model for India. In the current study, it is proved that there exists a negative impact of FDI on economic growth in short run. At this juncture, this study recommends three stage development for Indian economy. At the first stage, the article recommends proving economic growth the highest priority to bring FDI in India. At the second stage of development, policy makers need to find out which macroeconomic variables are positively influenced by inflow of FDI. At the final stage, policy makers need also to be ensured that these macroeconomic variables to work as a catalyst to augment economic growth ultimately in India. Thus, the motto of the policy makers needs to be directed in a way so that it can be ensured that despite providing negative influence on economic growth, FDI is helpful for Indian economy.

The long run cointegration proves there remains a trend in FDI and economic growth in India. Keeping this out in mind, it finds out the impact of economic growth on FDI in long run. Though the long run impact is not significant, the short run causality proves the importance of overall economic growth in enhancing the inflow of FDI in India. Though the short run influences of past periods of FDI values are significant on its own current values, the importance of economic growth can be judged through Berthélemy and Demurger (2000). Following this study, the current article also supports growth led FDI hypothesis in India. Although there are several studies on FDI led growth, the opposite has an example of very few. This study strongly confirms the importance of economic growth to call for FDI and then the significance of FDI in promoting short run economic growth. Hence, policies can be framed accordingly to first lay importance on enhancing economic growth and thereafter, a strong focus on boosting inflow of FDI. Correct implementation of FDI policies will bring economic growth and the loop follows. 


\section{CONCLUSION}

The article concentrates on finding the association between FDI and economic growth for a developing country, India. Conventional studies proved FDI led growth theory for any developing economy. Policy implications are made accordingly for reaping the benefits of the same. In contrast to that, the conceptual theory that this article proposes following Berthélemy and Demurger (2000), has the different characteristics prompting the need of framing growth focused policies than providing liberalization in the foreign funds at the initial level. Once, the fiscal and monetary policy are aligned and proved to be found successful in determining growth at its desirable level, the restructuring of FDI policies needs to be considered. During the growth phase of Indian economy, the study also proves to provide importance to strengthen the domestic investment sector besides its fiscal policies. As growth level is determined by GDP, the basic domestic investment can also be one of the contributors enhancing the level of national income. Thus, following Abu and Karim (2016), the study first suggests being prominent in domestic investment and then the gap of the requirement of capital can be considered from foreign investors, which ultimately, in short run, will create growth in India.

\section{REFERENCES}

[1] Abu, N., \& Karim, M. Z. A. (2016). The relationships between foreign direct investment, domestic savings, domestic investment, and economic growth: The case of Sub-Saharan Africa. Society and Economy in Central and Eastern Europe, 38(2), 193-217.

[2] Adedoyin, F., Bekun, F. V., Driha, M. O., \& Balsalobre-Lorente, D. (2020). The Effects of Air Transportation, Energy, ICT and FDI on Economic Growth in The Industry 4.0 Era: Evidence from The United States. Technological Forecasting and Social Change.

[3] Akisik, O., Gal, G., \& Mangaliso, M. P. (2020). IFRS, FDI, economic growth and human development: The experience of Anglophone and Francophone African countries. Emerging Markets Review, 100725.

[4] Ali, W., \& Mna, A. (2019). The effect of FDI on domestic investment and economic growth case of three Maghreb countries. International Journal of Law and Management.

[5] Alvarado, R., Iniguez, M., \& Ponce, P. (2017). Foreign direct investment and economic growth in Latin America. Economic Analysis and Policy, 56, 176-187.

[6] Asongu, S. A., \& Odhiambo, N. M. (2020). Foreign direct investment, information technology and economic growth dynamics in Sub-Saharan Africa. Telecommunications Policy, 44(1), 101838 .

[7] Berthélemy, J. C., \& Demurger, S. (2000). Foreign direct investment and economic growth: theory and application to China. Review of development economics, 4(2), 140-155.

[8] Billington, N. (1999). The location of foreign direct investment: an empirical analysis. Applied economics, 31(1), 65-76.

[9] Brainard, S.L. (1997), "An empirical assessment of the proximity-concentration trade-off between multinational sales and trade", American Economic Review, Vol. 87 No. 4, pp. 520544.

[10] Cadman, D. (2015). Effect of economic growth on foreign direct investment in Kenya (Doctoral dissertation, University of Nairobi).

[11] Canh, N. P., Binh, N. T., Thanh, S. D., \& Schinckus, C. (2020). Determinants of foreign direct investment inflows: The role of economic policy uncertainty. International Economics, 161, $159-172$. 
Foreign Direct Investment and Economic Growth: Two Equally Desirable Dilemmas of Policy Makers in India

[12] Chakrabarti, A. (2001). The determinants of foreign direct investments: Sensitivity analyses of cross-country regressions. kyklos, 54(1), 89-114.

[13] Culem, C. G. (1988). The locational determinants of direct investments among industrialized countries. European economic review, 32(4), 885-904.

[14] De Long, J. B. (1992). Productivity growth and machinery investment: a long-run look, 18701980. Journal of Economic History, 307-324.

[15] Dunning, J.H. (1988), "The eclectic paradigm of international production: a restatement and some possible extension”, Journal of International Business Studies, Vol. 19 No. 1, pp. 1-31.

[16] Fan, W., \& Hao, Y. (2020). An empirical research on the relationship amongst renewable energy consumption, economic growth and foreign direct investment in China. Renewable Energy, 146, 598-609.

[17] Fayissa, B., Nsiah, C., \& Tadasse, B. (2008). Impact of tourism on economic growth and development in Africa. Tourism Economics, 14(4), 807-818.

[18] Hanif, I., Raza, S. M. F., Gago-de-Santos, P., \& Abbas, Q. (2019). Fossil fuels, foreign direct investment, and economic growth have triggered $\mathrm{CO} 2$ emissions in emerging Asian economies: some empirical evidence. Energy, 171, 493-501.

[19] Hong, E., Lee, I. H. I., \& Makino, S. (2019). Outbound foreign direct investment (FDI) motivation and domestic employment by multinational enterprises (MNEs). Journal of International Management, 25(2), 100657.

[20] Hsieh, H. C., Boarelli, S., \& Vu, T. H. C. (2019). The effects of economic policy uncertainty on outward foreign direct investment. International Review of Economics \& Finance, 64, 377392.

[21] Jenkins, R. (2006). Globalization, FDI and employment in Viet Nam. Transnational corporations, 15(1), 115.

[22] Kumari, A., \& Sharma, A. K. (2018). Causal relationships among electricity consumption, foreign direct investment and economic growth in India. The Electricity Journal, 31(7), 33-38.

[23] Latif, Z., Latif, S., Ximei, L., Pathan, Z. H., Salam, S., \& Jianqiu, Z. (2018). The dynamics of ICT, foreign direct investment, globalization and economic growth: Panel estimation robust to heterogeneity and cross-sectional dependence. Telematics and Informatics, 35(2), 318-328.

[24] Lee, S.-W. (2007), "Foreign direct investment and export performance: the case of Taiwan", MSc thesis in Economics, Economics and Information Systems, University of Wollongong.

[25] Lee, I. H. I., Hong, E., \& Makino, S. (2020). The effect of non-conventional outbound foreign direct investment (FDI) on the domestic employment of multinational enterprises (MNEs). International Business Review, 101671.

[26] Lim, D. (1983). Fiscal incentives and direct foreign investment in less developed countries. The Journal of Development Studies, 19(2), 207-212.

[27] Lunn, J. (1980). Determinants of US direct investment in the EEC: Further evidence. European economic review, 13(1), 93-101.

[28] Makiela, K., \& Ouattara, B. (2018). Foreign direct investment and economic growth: Exploring the transmission channels. Economic Modelling, 72, 296-305.

[29] Osei, M. J., \& Kim, J. (2020). Foreign direct investment and economic growth: Is more financial development better? Economic Modelling.

[30] Pesaran, M., Shin, Y., Smith, R., 2001. Bounds testing approaches to the analysis of level relationships. Journal of Applied Econometrics 16, 289-326. 
[31] Qureshi, F., Qureshi, S., Vo, X. V., \& Junejo, I. (2020). Revisiting the nexus among Foreign Direct Investment, Corruption and Growth in Developing and Developed Markets. Borsa Istanbul Review.

[32] Raza, m (2020). The Relationship Between Domestic Investment and Quality Economic Growth in Thailand. International Journal for Quality Research, 14(3), 691-704.

[33] Schneider, F., \& Frey, B. S. (1985). Economic and political determinants of foreign direct investment. World development, 13(2), 161-175.

[34] Sokhanvar, A. (2019). Does foreign direct investment accelerate tourism and economic growth within Europe? Tourism Management Perspectives, 29, 86-96.

[35] Sunde, T. (2017). Foreign direct investment, exports, and economic growth: ADRL and causality analysis for South Africa. Research in International Business and Finance, 41, 434444.

[36] Tsai, P. L. (1994). Determinants of foreign direct investment and its impact on economic growth. Journal of economic development, 19(1), 137-163.

[37] Wang, C., \& Jiayu, C. (2019). Analyzing on the Impact Mechanism of Foreign Direct Investment (FDI) to Energy Consumption. Energy Procedia, 159, 515-520. 